\title{
'THE PROVERB IS THE DRUM OF GOD': ON THE USE OF AFRICAN PROVERBS IN THE INTERACTION BETWEEN AFRICAN CULTURE AND THE CHRISTIAN FAITH
}

\author{
Willie van Heerden \\ Department of Old Testament \\ University of South Africa
}

\begin{abstract}
An African theology of inculturation needs to take into consideration the oral literature of the African people, including their rich treasure of proverbs. However, African proverbs have been largely neglected in situations where the Bible is studied and taught on this continent. This article is a plea for a revaluation of African proverbs in such situations. I first propose a theological framework within which the study of African proverbs in dialogue with the Christian faith fits. Then certain characteristics of (African) proverbs that make them suitable instruments for the dialogue between culture and faith are discussed. Finally, I explore some opportunities for using African proverbs when we read or teach the Bible in Africa.
\end{abstract}

\section{Introduction}

A very wise old man said: "One of the things I often did when growing up as a boy... was to look after our family cattle, sheep and goats. This work was difficult, especially in the rainy season, when the fields and woods would be thick with vegetation. There were also dangers from snakes, jackals, wolves, or even leopards and hyenas... Out of this experience in my early years, I see clearly the Gospel and Culture rubbing shoulders when the Bible says: "The Lord is my shepherd; I shall not want; he makes me lie down in green pastures. He leads me beside still waters; he restores my life..." (Ps 23) As I went about in my youth looking after these animals, little did I realise that the Gospel was right there in front of me, right there around me, right there where I was. Where and when the gospel is proclaimed, it cannot be removed from the cultural letters all around us, since you cannot have the Gospel in a vacuum... One of the vital cultural elements in Africa is the proverb" (Mbiti 1995:1).

Even a number of world proverbs agree with this wise man, for they say that proverbs are little gospels (Spanish), or the voice of God (Japanese), or the drum of God (Punjabi) (Basgöz 1990:9).

"But proverbs have been neglected and unused in theological discourses", said this same wise man who has since become a renowned theologian, who is none other than John Mbiti. He also expressed his regret that he himself did not seize the many opportunities for using proverbs as a teacher, preacher, and theologian:

Have I personally used proverbs in my own theology? Honestly, not in an integrated way.

Shame! Have I unused them? Yes. Shame! Why? I must analyse myself, to see why I have missed the largely still empty boat - maybe I can still jump on board (Mbiti 1995:10).

This article is an attempt to go for the carrot that Mbiti holds in front of our noses. My thesis is that African proverbs provide a unique opportunity for empowering people who want to read and teach the Bible authentically.

But, you may ask, why are you pushing the matter? Can't you leave it to those who can benefit most from it? Can you speak with authority on African culture? No, I cannot, but I 
know when I am fascinated by something and I hope that people will not take offence when I volunteer to carry the straw for the roof of the house which they know how to build - even at the risk of being frowned upon. My situation reminds me of an Akan proverb: When foreigners [your enemy] dance your dance they just push out their buttocks (Ganda, Uganda) (Opoku 1997:80). I admit that African proverbs allow me to peep just a little into a wonderful reality of which I understand very little, but which, I believe, is a powerful tool for the empowerment of African people. The following proverb probably also applies to me: I pointed out to you the stars (moon) and all you saw was the tip of my finger (Sukuma, Tanzania) (Healey and Sybertz 1996:17).

I shall first propose a theological framework within which the study of African proverbs in dialogue with the Christian faith fits. Then certain characteristics of (African) proverbs that make them suitable instruments for the dialogue between culture and faith will be discussed. Finally, I shall explore some opportunities for using African proverbs when we read or teach the Bible in Africa.

\section{A framework: An African theology of inculturation}

The quest for identity which is evident in African theology demonstrates that African Christianity is repeating in our own time the encounter that characterised the early centuries, between the infant faith and the pagan milieu in which it found itself (cf Maluleke 2001:29). By embracing the faith of the Gospel, the Christians did something that had drastic implications in their Greco-Roman culture: Many Christians dissolved the sacred ties of custom and education, violated the religious institutions of their country, and presumptuously despised whatever their fathers had believed as true, or had reverenced as sacred. In order to fashion an identity, they needed to come to terms with the various facets of the Greco-Roman culture from which they themselves had emerged (cf Maluleke 2001:30). This problem was to occupy the minds of early Christian apologists, for sooner or later the converts had to settle accounts with their past in order to establish an authentic Christian identity within their culture (cf Bediako 1992:32). Bediako concludes that the works of twentieth-century African theologians and those of second-century Christian apologists can be read analogically. Both groups of thinkers have faced, for example, the challenges of synthesising the various and disparate sources which make up the total religious experience of Christians, which included options like inculturation or a total rejection of previous culture (cf Maluleke 2001:31).

Presently there are two major directions in African theology: inculturation, which stresses Africa's religio-cultural realities and finds expression in the narrowly defined "African theology" (now inculturation theology), and liberation, with its emphasis on the continent's politico-socio-economic realities, which finds expression not only in Black Theology in South Africa, but also in African liberation theology and African women's theology. While the term "contextualization" may be a more inclusive term, I will continue to use the widely-used expression "theology of inculturation" in a broad sense to include not only culture, but also the social, economic and political reality of Africa and South Africa in particular.

Ukpong (1995:5) says that an inculturation hermeneutic designates an approach to biblical interpretation which seeks to make the African, and for that matter any socio-historical context, the subject of interpretation. This is different from making another context the subject of interpretation and then applying the result in the African context. It is also different from reading the African context into the biblical text. He proposes that Africans read the Bible "with African eyes", which means that the experiences of Africans inform their Bible reading and the resources of the African socio-cultural context are utilised.

One important source of an African narrative theology of inculturation is comprised of the 
proverbs, sayings, riddles, stories, songs and other examples of African oral literature. These sources are a challenge to broaden our horizons, to explode our petty images of God and of one another, and to enter with wonder deeper and deeper into the mystery. A Ganda proverb says: The person who has never traveled widely thinks his mother is the only cook (the best cook) (Healey and Sybertz 1996:361).

The encounter of African culture with Christianity brings a newness, a freshness, an originality, a difference like a spice that brings a new taste to food. In one way it is the same food (core Christianity), but it tastes very different, say Healey and Sybertz (1996:20). In the encounter between culture and faith, there is a mutual enrichment and ongoing dialogue. The cultural values and grassroots experiences of the African local churches enrich the world Church and world Christianity. In turn the experiences and insights of the world Church and world Christianity challenge and enrich the African cultures and local churches. There is mutual illumination.

On the inside cover page of the report of one of the very first conferences on the African continent about Christianity and Africa (1955 in Accra, Ghana) the following proverb was quoted: In the beginning, God gave every people a cup, a cup of clay, and from this cup they drank the water of life. They all dipped in the water, but their cups were different (cf Mbiti 1995:2). That is an early attempt to express the foundations of a theology of inculturation.

In southern Africa, concern for a theology of inculturation has been less evident than elsewhere, claims Mbiti (1995:10). According to him the main reason for this has been the demands of the struggle for liberation from apartheid.

Liberation theology has not discovered or used proverbs. Now that the goal of the struggle has legally and democratically been reached in 1994, there will be more interest in African Culture and its relation to the Gospel (Mbiti1995:10).

The final statement of a consultation on African Proverbs and Christian Mission held in Maputo, 1995, reads (Healey and Sybertz 1996:30):

The cultures, churches and scholarship in the northern and western continents have not sufficiently recognized the importance of proverbs. Western theological methodology has not taken proverbs and narrative theology seriously enough probably due to a different appraisal of proverbs. Proverbs and stories have not been considered part of proper academic theological discourse since they do not fit the propositional style and framework of theologizing. Out of fear, oversight or various pressures even African theologians and African theological conferences have not used proverbs efficiently.

To conclude this section: An African Theology of inculturation can be the place where African proverbs play a valuable part, although in South Africa this theological framework has not received the following it deserves.

\section{Characteristics of (African) proverbs that make them suitable instruments for the dialogue between culture and faith}

Several interesting metaphors have been used to describe the potential interaction between African proverbs and the Gospel. George Cotter (1997:262) associates them with a bridge:

Brooklyn Bridge in New York is suspended from huge cables that are woven together from millions of small wires. These tiny wires support the heavy roadway that connects the two shores, allowing people to pass from one shore to another. I feel these wires are like proverbs, little things that tie the Lord to the people allowing revelation and prayer to pass back and forth.

Others call them windows, as Bennett (1997:241) says:

The question is: How do we communicate biblical values, the values contained in the 
gospel, at a people's worldview level? I suggest that we must find a window, an access point, into their worldview. One window into a people's worldview can be found and developed through an analysis of their traditional proverbial lore. Once we have sufficiently understood the nature of the window, we can then build communication bridges through this window between worldview values and biblical values.

Still others say proverbs are part of Passover language. According to John Pobee (1996:164165), if the faith of the Africans is not to die, it must become a vision of a world that they can feel is theirs... There is an urgent need to reject present foreign models of expression if we are to breathe new life into the Spoken Word. Our church must express a Passover of Language, or the meaning of the Christian message will not be understood. One of the primary tasks of Christian reflection in Black Africa is to totally reformulate our basic faith through the mediation of African culture ... as expressed in proverbs, art, music, liturgy, poetry, stories and biography.

These metaphors suggest that proverbs are the structures which make open communication possible where cultural gaps exist; they are ways of disclosing oneself to others; and they provide a language which enhances meaningful communication of the Gospel.

But I have not even mentioned perhaps the most striking metaphor: Anne Nasimyu-Wasike calls proverbs the unwritten Bible of the African people (cf Healey and Sybertz 1996:28) and Healey and Sybertz (1996:29) remark that proverbs constitute the scriptures as well as the breviaries of African Traditional Religions. In this case African proverbs are described in terms of the Bible.

Incidentally if we want to be bold, we can claim that a statement about Turkish proverbs in their relation to the Moslem faith applies to African proverbs in their relation to the Christian faith: A Turkish proverb says: The proverb does not enter the Kur'an (is not the word of God), but it runs neck-to-neck with it in value (cf Basgöz 1990:13).

The above metaphors seem appropriate in view of certain characteristics of proverbs in general, and those from Africa in particular:

They speak with authority

A point that is supported by a proverb appears to be more convincing because proverbs, being part of people's cultural heritage, reinforce the traditional beliefs and norms of the society. It is hardly possible to query or doubt the validity of a point supported by a proverb (Pachocinski 1996:9).

The Afrikaans author and poet, Hennie Aucamp (1994:3), personally experienced the authority associated with proverbs and sayings:

...dis waarskynlik my ma wat my liefde vir die gedronge sêding die sterkste gevestig het. Sy het haar waarhede op die koop toe met soveel gesag uitgespreek dat jy haar aforismes as Bybelwaarhede aanvaar het.

(...it is probably my mother who most powerfully established my love for the terse saying. Besides, she expressed her truths with so much authority that one accepted her sayings as Bible truths.)

They are an effective tool for communication

Several proverbs underline the communicative value of proverbs, for example: The proverb is the torch in conversation (Bosnian), or The proverb is a horse to conversation; when the conversation droops, it revives it (Yoruba, Nigeria) (Basgöz 1990:9).

They affirm the participation of all the people

Proverbs are the affair of the nation (Congolese) (Basgöz 1990:9).

The proverb is the wisdom of the street (German) (Basgöz 1990:9). 
They reflect the experiences of all the people

Proverbs are the children of experience (English) (Mieder 1993:5).

Each proverb is the Amen of an experience (German) (Spicker 1994:164).

Many proverbs are characterised by their religious content and deep spirituality (cf Mbiti, in Opoku 1997:xii, xiii)

This is evident from all the African proverb collections I have consulted.

It is noteworthy that many of the proverbs that are quoted in the Bible are not religious at all. Furthermore, at least three proverb collections in the book of Proverbs are attributed to foreign sources (22:17-24:22; 30:1-14; 31:1-9) (cf Crenshaw 1998:60). Still others were quoted cross-culturally between hostile groups (eg Jdg 8:21). Beardslee ([1981]1994:169) points out that, according to the Synoptic Gospels, proverbs function in at least two ways in the words of Jesus. On the one hand he used them to illustrate an idea, but on the other hand, he used them as disjunctive "jolts" that challenge the status quo or demand reorientation.

\section{Opportunities for using African proverbs when we read or teach the Bible in Africa}

When we narrow our focus down to reading and teaching the Bible, I want to encourage the use of African proverbs in interaction with biblical texts for three reasons:

- There is a close association between (African) proverbs and instruction or teaching.

- Studying how Africans use their proverbs offers valuable insights into the art of interpretation.

- Comparing what African proverbs and biblical texts say on specific topics, is a fascinating endeavour.

4.1 The close association between (African) proverbs and instruction or teaching Nyembezi (1954:xii) explains:

All proverbs, whatever situation they describe, be they humorous or grim, seem to have a common base in that they may all serve to instruct. It would not be correct, however, to say that the proverbs are framed with the specific purpose of teaching. What happens is that the expression, after being evolved, may be regarded by the people as an appropriate means of instructing.

Metaphors constitute an important marker for many proverbs, and it is exactly this vivid imagery of most proverbs that makes them so appealing to us. This feature of proverbs makes learning more memorable and effective, because it moves from the familiar to less familiar, and it provides a mechanism for the changing of our modes of representing reality, in thought and language (cf Van Heerden 1997:234).

Furthermore, the beauty and uniqueness of proverbs catch the attention of, and invite the involvement of, the hearer.

\subsection{African proverbs and the art of interpretation}

When we study African proverbs in an attempt to learn more about the art of interpretation, a whole new world opens to Bible readers.

The importance of taking context into account

Those who publish proverb collections find it difficult to provide the meaning of a proverb, 
since they were collected "out of context". Dzobo (1975:xi) explains this dilemma as follows:

I have attempted to bring out the general lessons of the proverbs as much as possible. This, however, does not limit the number of different contexts within which a proverb can be used with slightly or completely different meanings. Proverbs in actual use always refer to social situations. This social context gives meaning to a particular proverb, for a proverb in a collection that merely enumerates uncontextualised proverb texts is for all general purposes meaningless. This is why, even in actual use, many African proverbs require an extensive commentary.

Jan Knappert (1989:3) examines two Damara proverbs:

If you have a cup of sweet milk, be content, and An ugly object may hide something sweet; both refer to a particular scene from life in the deserts of Namibia (the word Namibia means "desert country") where a certain gnarled and knotty tree of the doringboom [thorn tree] type grows. The hard outer bark is layered on the inside with a soft inner bark, a fibrous substance which contains a syrupy liquid, not unlike molasses but sweeter. The Damara love to drink their milk in the shade of this tree; they cut off strips of the bark, dip the inner bark in their milk and then suck it. Sitting around together and drinking this sweet milk is the Damara's chief delight. So the proverb means that no-one should ask for more than to sit in the shade of this ugly tree and drink his [or her] sweet milk: the wisdom of being content with simple things. The other proverb arising out of this situation signifies that ugly objects or people may well contain sweetness and goodness.

This works the other way too, says Jan Knappert (1989:2):

A proverb like Wisdom is more precious than rubies (Pr 3:15) would be meaningless to a San living in the desert who possesses no wealth, no luxuries, and no ornaments except a few iron beads or plaited bracelets. Only by placing a given proverb in its cultural background can we understand its meaning and in doing so gain some insight into different peoples' ways of life and thinking... Thus every proverb requires a little story to explain why the proverb was phrased as it is. For instance, the proverb Wisdom is more precious than rubies was intended for princes. The average inhabitant of Solomon's kingdom never saw rubies, but the king's many lazy sons were more interested in jewels than they were in the art of governing the kingdom. This proverb, like most of its kind, was originally meant to be taken literally...

Therefore, Bible reading and Bible teaching is impossible if we ignore the different contexts which are part of the complex process of interpretation.

\section{Semantic indefiniteness and perspectivity}

Many African proverbs force us to deal with the issues of multiple meanings and seemingly contradictory statements. Only naive Bible readers will claim that these issues are irrelevant to Bible reading. It is exactly the metaphor of the proverb that enables us to employ proverbs in many different contexts and as a result create different meanings. Barbara KirschenblattGimblett ([1981]1994:113) lists four sources of a proverb's multiple meaning: what is understood by the image presented in the metaphor; what is understood as the general principle expressed by the metaphor; how the general principle is evaluated; and the requirements of the situation in which the proverb is used, regardless of what one actually believes in principle.

The possibility of multiple meanings may be viewed as unfortunate or as a way of weaseling out of the interpreter's responsibility. I view it as a challenge to interpreters to allow the proverb to provoke and challenge their minds.

Numerous articles have appeared on, or references have been made to, tensions between proverbs. The following titles of articles serve as examples: "How paradox means" (Norrick 
1989); "The ethicality of Igbo contrary proverbs" (Nze:1990); "The proverbial truth: Contextually reconciling and the truthfulness of antonymous proverbs" (Furnham 1987); "Do proverbs contradict?" (Yankah 1984) and "Are African proverbs an ambiguous source of wisdom for living? A case study of Ga and Dangme proverbs" (Kudadjie 1997). Proverbs always refer to situations, and because situations differ, we find that some proverbs seem to be contradictory. That is to be expected if we remember that there are always more angles than one from which to look at a problem (cf Nyembezi 1954:xii). Are we really doing the Bible and students of the Bible a favour when we harmonise texts between which we perceive tension?

\section{Orality versus textuality}

During field-work concerning the relationship between literary study of the Bible and its actual use among grassroots groups of black Christians in South Africa, Jonathan Draper (1996:65) noticed that the communities had a reverential attitude to the Bible, but it did not mean that they wished to read it. The holy status of the Bible was symbolic and not literary. In fact, there was a resistance to beginning to read, since there was a feeling that interpretation was for religious experts. What emerged was an unresolved tension between oral and textual cultures. The introduction of a technique which demanded a close reading of the text, standing by itself, was an alien and suspicious idiom (Draper 1996:65).

Mazamiza (cf Draper 1996:72) has put his finger on the centrality of this conflict for black students entering the world of Biblical Studies in the academy:

Textuality for the black biblical scholar is a form of resocialisation process to the extent that it is in discontinuity with previous socialisation (oral tradition). Through the resocialisation process the trained reader negotiates a new identity in a new universe of discourse. The new universe of discourse is learned and internalised in the form of literacy. Textuality is a movement away from orality to literacy.

That movement is experienced as loss, and all too often it is not clear to students what gain is made in compensation. But introducing African proverbs in situations where black students attempt to deal with the biblical text on its own, can provide the link with the oral culture. It is possible to work in complementary fashion with residual oral culture in a way which respects and recovers its insights, and yet contributes the analytical and transformative insights of textual culture also.

By taking African proverbs seriously, we are thus forced to rethink our views on textuality. Willem Saayman (2001) mentioned to me the notion of "reducing language to text" when we discussed the use of African proverbs for preaching and teaching. We are heirs to the process of alienation from the oral world produced by writing and print. We have internalised it until it seems natural, and we do not recognise that there is another world view. But there is a power dynamic to it as well. There is always a power dynamic to text, since it freezes the word and places it in the hands of interpretive experts. According to Max Weber (cf Draper 1996:75) the oral words of the prophet are reduced to text and the priest re-establishes control by becoming guardian and interpreter of the text. African oral theology is a living reality. We must come to terms with it and we must acknowledge its role in the total life of the church. According to Mbiti (cf Healey and Sybertz 1996:22), oral theology is the most articulate expression of theological creativity in Africa. This form of theology gives the church in Africa a certain measure of theological selfhood and independence.

For Biblical Studies syllabi to be relevant to the African people, the implications of these insights regarding orality versus textuality should be taken seriously. Not only the use of African proverbs, but also reflection on their use in oral cultures might become valuable elements of the syllabi. 


\section{What is lost in translation}

Students of the Bible who have not studied the original languages of the Bible, cannot fully appreciate how much of the impact of the text is lost in translation. Likewise, several collectors of African proverbs have bemoaned the fact that so much is lost in translation, for many collections are aimed at the English-speaking market. Very little of the literary beauty, for example wordplay, can be appreciated in the translations. Again, the use of African proverbs can help students to picture the loss, if the proverbs are used in both the local African language and in translated form.

\section{African proverbs can be used to illustrate certain principles of interpretion}

Many proverbs contain imagery that beautifully illustrates certain principles of interpretation. In a Biblical Studies textbook I use more than thirty African proverbs for this purpose. A few examples will suffice (Van Heerden 1999:10,57,69,72,87,137):

A bird does not impulsively change the way it builds its nest (Lugbara, Uganda).

I use this proverb to illustrate the idea that people are resistant to change and will not easily give up their deep-rooted ideas about the Bible.

The tortoise says that it is good to walk fast and it is good to walk slowly (Akan, Ghana). This proverb features in a discussion on the interpretation of seemingly contradictory texts, for example Proverbs 26:4 and 5 which reads: "Do not answer fools according to their folly, or you will be a fool yourself. Answer fools according to their folly, or they will be wise in their own eyes."

Wisdom is not found in only one person's house (Basotho).

This proverb illustrates the principle of intersubjectivity, which is expressed in a very special way in cultures where group ties are very strong.

A neighbouring country is merely the border; something you don't know is just sweat (Oromo, Ethiopia).

This proverb is used in a discussion of the patterning nature of our thoughts. Experiences are meaningful to us when we can link them up with existing thought patterns. The proverb illustrates what happens when we are confronted by the totally unfamiliar.

The home of the frog is both in the water and on the land (Lugbara, Uganda).

This proverb implies that unlike what is suggested by the way of life of frogs, people cannot live in two worlds at the same time. To be more specific, people cannot hold two contradictory views at the same time. The proverb illustrates the principle of non-contradiction.

Cattle in the same kraal butt each other (Sotho).

This proverb illustrates the idea that the most serious conflicts often take place between people who live close together: they live in the same house, or belong to the same church. Most "battles" about the interpretation of the Bible are "in-house" battles.

4.3 When African proverbs and biblical texts cover the same topics

When we attempt to compare African proverbs with Bible texts, a word of caution is apt. First, comparison is not limited to similarities only, and second, we should not rush into using African proverbs to explain biblical texts or concepts without considering contextual matters. John Pobee (1995) calls this technique the "remote control" approach, where proverbs are used like the buttons on a remote control device. When a button is pressed, it immediately activates a 
desired channel. This warning should be heeded by everybody working with narrative and oral material. All stories and proverbs are particular to their contexts in a sense.

However, when comparisons are made responsibly, the following relationships between proverb and biblical text may occur, according to Kudadjie (1996):

- What the Gospel affirms,

- what the Gospel adds,

- what the Gospel corrects or replaces,

- values which local proverbs add to biblical emphases.

Nussbaum (1996) offers a slightly different list of types of proverb application to biblical texts:

- Decorating the meaning with humour or vivid imagery,

- clarifying through illustration,

- making the point through contrast with a traditional proverb,

- modifying or extending a traditional proverb in view of biblical definitions,

- modifying or extending the biblical text in view of African definitions.

Let me give a few examples of useful parallels between African proverbs and biblical texts. Father George Cotter (1991) wrote a book containing the text of the four Gospels and hundreds of parallel proverbs of the Oromo people from Ethiopia. Both the biblical text and the proverbs are in the Oromo language. On each page the biblical text appears on the left and the corresponding proverbs on the right, next to the relevant biblical passage. During a conference on "The African Proverb in the $21^{\text {st }}$ Century", Cotter (1997:267-268) referred to this book and listed some examples. I select a few:

Matthew 2:11

On coming to the house, (the Magi) saw the child with his mother Mary, and they bowed down and worshipped him. Then they opened their treasures and presented him with gifts of gold and of incense and of myrrh.

As coffee is not taken without a morsel, so a king is not visited without a gift.

John 3:16

For God so loved the world that he gave his one and only Son, that whoever believes in him shall not perish but have eternal life.

She had only one lamb, and this one she slaughtered for her guest.

Matthew 5:37

Simply let your "Yes" be "Yes", and your "No", "No"; anything beyond this comes from the evil one.

Speech and a stick for the donkey are best when [straight and] short.

Luke 11:8

I tell you, though he will not get up and give him the bread because he is his friend, yet because of the man's persistence he will get up and give him as much as he needs.

By persevering the egg [eventually] walks on legs.

Matthew 6:24

No one can serve two masters. Either he will hate the one and love the other, or he will be devoted to one and despise the other. You cannot serve both God and Money.

The dog that eats at two houses will be eaten in between by a hyena. 


\section{Matthew 7:4}

How can you say to your brother, "Let me take the speck out of your eye," when all the time there is a plank in your own eye?

The dog, not seeing its own back end, says to the goat, "Hold your tail down!"

Evans J Nyakundi selected eighty Gusii proverbs (Kenya) for which he could find biblical parallels, for example [Nyakundi (s a):22,30]:

The cow ate Nyankuru's (a person) finger, only the joint is left.

Explanation: Cows are a symbol of wealth. Doing dishonest work as a source of living is harmful and dangerous to everyone in the society. Nyankuru suffered injuries after trying to acquire riches dishonestly.

Biblical parallel: "For the wrongdoer will be paid back for whatever wrong has been done" (Col 3:25).

The dry skull laughs at the one which is fresh.

Explanation: Many people do not see their own failures but find it easier to point fingers at others' failures. There are those who rejoice at others' problems without realising that they too may face a similar situation. The proverb warns those who are watching others more than themselves.

Biblical parallel: "You hypocrite, first take the log out of your own eye, and then you will see clearly to take the speck out of your neighbour's eye" (Mt 7:5).

Another rich source of African proverbs in dialogue with the Christian faith is the African Proverbs, Sayings and Stories website (http://www.afriprov.org). An e-mail discussion list (proverbs-list@afriprov.org) is associated with the website. The sponsor and host of the website is the Urban Ministries Support Group (UMSG) in Nairobi, Kenya. The administrator of the website is Mr. Nicholas Adongo, based in Nairobi, Kenya and the Moderator is Rev. Joseph Healey who resides in Dar es Salaam, Tanzania. The welcome message on the website states:

What is unique is that the origin and starting point is Africa itself. With the renewed interest in African oral literature and African culture in general we try to provide a forum for people like you to share your interest and experiences in researching, collecting, writing about and using African proverbs, sayings and stories.

I want to make special mention of the African Proverb of the Month section of this churchsponsored website. Every month since June 1998 one African proverb is explained in some detail and special attention is given to its possible application in ministry. References are made to biblical parallels. I summarise the discussion of the proverb of the month for March 1999: (This proverb is discussed by Rev. Healey, although contributions from people living in all parts of Africa have been used for the Proverb of the Month section. A Zulu proverb, the groin pains in sympathy with the sore, was used for April 2000).

Proverb: Let the guest come so that the host or hostess may benefit (get well).

Explanation: The guest or visitor brings many blessings for the local people and home.

Traditionally the proverb had different levels of meaning:

- The arrival of a guest meant a big meal of welcome. It was a special time of happiness for the children and a break from some of the ordinary chores.

- The guest brought gifts for the host or hostess and the family members. If the visitor came with news of a death in his or her family this could also be considered a type of 
gift - the guest was offering himself or herself in real life.

- The guest brought new things (for example medicine, seeds) that could help the life of the local residents.

- The guest brought news of relatives and friends living in other parts of the country.

John Mbiti is then quoted: "Hospitality and tender care are shown to visitors, strangers and guests. In the eyes of the African peoples the visitor heals the sick (another African proverb). This means that when a visitor comes to someone's home, family quarrels stop, the sick cheer up, peace is restored, and the home is restored to new strength. Visitors are, therefore, social healers - they are family doctors in a sense."

The author states that there are very interesting parallels to Jesus Christ in this Swahili proverb. One of the African names for Jesus Christ is "Our Guest". Through the incarnation Christ became the most important guest of all time. He loved humankind enough to join the human race. He was the guest of the shepherds in Bethlehem; the guest of Joseph and Mary in the manger; the guest of Zacchaeus the tax collector ("...hurry and come down; for I must stay at your house today" (Lk 19:5).

The following theological parallels are also suggested:

- Jesus comes to people as guest in the Eucharist, the source and summit of the Christian life and the sign and sacrament of union with the risen Christ and with each other.

- Jesus brought the best gift possible: reconciliation between human beings and God.

- Jesus is the saviour who comes as the guest who heals. The "Great Healer" heals people of all sicknesses - physical, psychological and spiritual. His holistic healing resonates deeply with African people.

Jan Knappert (1995:6) goes one step further than the dialogue between existing African proverbs and biblical texts. He proposes that biblical scholars and missionaries in cooperation with African mother tongue speakers, especially poets, make new proverbs in the African languages on the basis of biblical proverbs and other biblical texts. The biblical text can be rephrased according to the rules of prosody that can be formulated on the basis of an analysis of the existing proverbs in that language.

Knappert's proposal is based on a phenomenon that has already occurred in many languages and cultures. The languages of most cultures for which the Bible is the major spiritual book contain between three hundred and five hundred proverbs that stem from the Bible (cf Mieder 1990:12). Many Anglo-American proverbs are (almost) identical to texts of the King James Bible, but some were coined as allusions to certain biblical passages. These are not direct quotes from the Bible, but merely wisdom of biblical origin. They are the products of people who had the skill to find the aesthetic form and structure necessary for a statement to become a proverb. Thus, while the Bible states: He that spareth his rod hateth his son: but he that loveth him chasteneth him betimes (Pr 13:24), the English folk proverb instructs more succinctly: Spare the rod and spoil the child. Other rephrasings and allusion to biblical passages include the current It is not good to eat much honey ( $\operatorname{Pr} 25: 27)$; The devil can cite Scripture for his purpose (Mt 4:6); Birds of a feather flock together (Ecclus 27:9); Man proposes, God disposes (Pr 16:9); and even the proverbial weather forecast Red sky at night, is a shepherd's delight, red sky in the morning, is a shepherd's warning (Mt 16:2-3) (cf Mieder 1990:11-12).

In English, at least 425 distinct proverbs have their origin in the Bible, says Mieder (1990:12). Of these 212 are from the Old Testament, 31 are from the Apocrypha, and 182 are from the New Testament (cf Mieder 1990:12).

However, such proverbs in modern languages which allude to the Bible do not necessarily function according to Knappert's hopes. Many of them are not deeply religious or sacred (any 
more). Furthermore, some of them are anyway downright questionable, especially in modern societies, like the chauvinistic A woman is the weaker vessel (1 Pt 3:7).

\section{Conclusion}

A statement by the Second Vatican Council conveys the spirit of my article (cf Healey 1996:50):

Let [the people] be familiar with their national and religious traditions, gladly and reverently laying bare the seeds of the Word which lie hidden in them...thus they themselves can learn by sincere and patient dialogue what treasures a bountiful God has distributed among the nations of the earth. But at the same time, let them try to illumine these treasures with the light of the gospel, to set them free...

The fascinating proverbs of the African people are one of the treasures a bountiful God has distributed among them. I believe that serious dialogue between the Christian faith and African culture can be enriched by utilising the interaction between African proverbs and the scriptures of the Christian faith. A good place to practise this interaction is where people study and teach the Bible.

\section{BIBLIOGRAPHY}

Aucamp, H 1994. Verkook tot 'n ekstrak: Gedagtes oor aforismes, na aanleiding van "Pluk die dag”. Talk given at Die Boekesentrum, Cape Town, 28 February 1994.

Basgös, I 1990. Proverbs about proverbs or folk definitions of proverbs. Proverbium 7, 7-17.

Bediako, K 1992. Theology and identity. The impact of culture upon Christian thought in the second century and modern Africa. London: Regnum.

Bennett, PA 1997. Traditional proverbs on marriage as a communications bridge between the Christian Gospel and the Bemba of Zambia, in Saayman, W (ed.), Embracing the baobab tree: The African proverb in the $21^{s t}$ century, 241-259. Proceedings of the Interdisciplinary Symposium on The African Proverb in the $21^{\text {st }}$ Century, University of South Africa, Pretoria, 2-7 October 1996. African Proverbs Series 5. Pretoria: Unisa Press.

Cotter, G 1991. Gurra Miti Qalbi Male: Wangela Goftaa Yesus Kiristosif Mamaaksa Oromo. Addis Ababa: United Printers.

Cotter, G 1997. The work of evangelisation and the gathering of proverbs, in Saayman, W (ed.), Embracing the baobab tree: The African proverb in the $21^{\text {st }}$ century, 260-269. Proceedings of the Interdisciplinary Symposium on The African Proverb in the $21^{\text {st }}$ Century, University of South Africa, Pretoria, 2-7 October 1996. African Proverbs Series 5. Pretoria: Unisa Press.

Crenshaw, JL 1998. Old Testament wisdom: An introduction. Revised and enlarged. Louisville, Kentucky: Westminster John Knox Press.

Draper, JA 1996. Confessional Western text-centered biblical interpretation and an oral or residual-oral context. Semeia 73, 59-77.

Dzobo, NK 1975. The moral value of Ewe proverbs. African proverbs: Guide to Conduct vol. 2. Accra:Waterville Publishing House.

Furnham, A 1987. The proverbial truth: Contextually reconciling and the truthfulness of antonymous proverbs. Journal of Language and Social Psychology 6/1, 49-55.

Healey, J and Sybertz, D 1996. Towards an African Narrative Theology. Nairobi: Paulines Publications Africa.

Kirschenblatt-Gimblett, B (1981) 1994. Toward a theory of proverb meaning, in Mieder, W 
and Dundes, A (edd.), The wisdom of many: Essays on the proverb, 111-121. Madison, Wisconsin: The University of Wisconsin Press.

Knappert, J 1989. The A - Z of African proverbs. London: Karnak House.

Knappert, J 1996. The use of proverbs for the evangelisation of Africa. Unpublished paper, read at the Interdisciplinary Symposium on The African Proverb in the $21^{\text {st }}$ Century, University of South Africa, Pretoria, 2-7 October 1996.

Kudadjie, JN 1996. Using Ga and Dangme proverbs for preaching. African Proverbs: Collections, Studies, Bibliographies. CD developed for the African Proverbs Project. Colorado Springs: Global Mapping International.

Kudadjie, JN 1997. Are African proverbs an ambiguous source of wisdom for living? A case study of Ga and Dangme proverbs, in Saayman, W (ed.), Embracing the baobab tree: The African proverb in the $21^{\text {st }}$ century, 176-191. Proceedings of the Interdisciplinary Symposium on The African Proverb in the $21^{\text {st }}$ Century, University of South Africa, Pretoria, 2-7 October 1996. African Proverbs Series 5. Pretoria: Unisa Press.

Maluleke, TS 2001. Identity and integrity in African Theology: A critical analysis. Religion and Theology 8/1, 26-41.

Mbiti, JS 1995. The Gospel and African culture: Use and unuse of proverbs in African Theology. Paper presented at a consultation on African Proverbs and Christian Mission in Maputo, 27-31 March 1995.

Mbiti, JS 1997. The ethical nature of God in African religion as expressed in African proverbs, in Saayman, W (ed.), Embracing the baobab tree: The African proverb in the $21^{\text {st }}$ century, 139-162. Proceedings of the Interdisciplinary Symposium on The African Proverb in the $21^{\text {st }}$ Century, University of South Africa, Pretoria, 2-7 October 1996. African Proverbs Series 5. Pretoria: Unisa Press.

Mieder, W 1990. Not by bread alone: Proverbs of the Bible. Shelburne, Vermont: The New England Press.

Mieder, W and Dundes, A (edd.) [1981]1994. The wisdom of many: Essays on the proverb. Madison, Wisconsin: The University of Wisconsin Press.

Norrick, NR 1989. How paradox means. Poetics Today 10/3, 551-562.

Nussbaum, S 1996. Missiological or moral. African Proverbs: Collections, Studies, Bibliographies. CD developed for the African Proverbs Project. Colorado Springs: Global Mapping International.

Nyakundi, EK [s a]. The Gusii proverbs. Nairobi: Published by the author.

Nyembezi, CLS 1954. Zulu proverbs. Johannesburg: Witwatersrand University Press.

Nze, C 1990. The ethicality of Igbo contrary proverbs. Africana Marburgensia 23/1, 12-22.

Opoku, KA 1997. Hearing and keeping: Akan proverbs. African Proverbs Series 2. Pretoria: Unisa press.

Pachocinsky, R 1996. Proverbs of Africa: Human nature in the Nigerian oral tradition. St. Paul, Minnesota: Professors World Peace Academy.

Pobee, JS 1995. An expression he used during a consultation on African Proverbs and Christian Mission in Maputo, 27-31 March 1995.

Pobee, JS 1996. Bible study in Africa: A Passover of language. Semeia 73, 161-179.

Saayman, W (ed.) 1997. Embracing the baobab tree: The African proverb in the $21^{\text {st }}$ century, Proceedings of the Interdisciplinary Symposium on The African Proverb in the $21^{\text {st }}$ Century, University of South Africa, Pretoria, 2-7 October 1996. African Proverbs Series 5. Pretoria: Unisa Press.

Saayman, W 2001. Informal interview with the author at the University of South Africa, 3 April 2001. Spicker, F 1994. Aphorismen über Aphorismen: Fragen über Fragen. Zur Gattungsreflexion 
der Aphoristiker. ZfdPh 113/2, 161-198.

Ukpong, JS 1995. Rereading the Bible with African eyes: Inculturation and hermeneutics. Journal of Theology for Southern Africa 91, 3-14.

Van Heerden, SW 1997. Faith is caught rather than taught: The significance of African proverbs for the inculturation of the Christian faith, in Saayman, W (ed.), Embracing the baobab tree: The African proverb in the $21^{\text {st }}$ century, 227-240. Proceedings of the Interdisciplinary Symposium on The African Proverb in the $21^{\text {st }}$ Century, University of South Africa, Pretoria, 2-7 October 1996. African Proverbs Series 5. Pretoria: Unisa Press.

Van Heerden, SW 1999. Making sense of, and with, the Bible: Bible reading in a complex world. Pretoria: Unibibsa.

Yankah, K 1984. Do proverbs contradict? Folklore Forum 17, 2-19.

\section{Electronic resources:}

African Proverbs: Collections, Studies, Bibliographies 1996. CD developed for the African Proverbs Project. Colorado Springs: Global Mapping International.

African Proverbs, Sayings and Stories Website: http://www.afriprov.org 